ARAŞTIRMA / RESEARCH

\title{
Pregnancy outcomes of patients with rheumatoid arthritis
}

\author{
Romatoid artrit hastalarının gebelik sonuçları

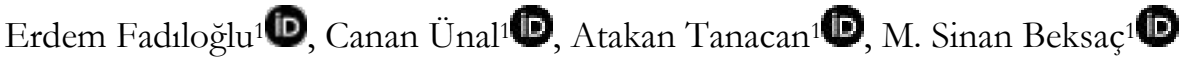 \\ ${ }^{1}$ Hacettepe University Division of Perinatology, Department of Obstetrics and Gynecology, Ankara, Turkey
}

\begin{tabular}{|c|c|}
\hline \multicolumn{2}{|c|}{ Cukurova Medical Journal 2020;45(2):518-525 } \\
\hline Abstract & $\ddot{O} z$ \\
\hline $\begin{array}{l}\text { Purpose: The aim of this studywas to evaluate the } \\
\text { obstetric outcomes of women with rheumatoid arthritis } \\
\text { (RA) } \\
\text { Materials and Methods: This retrospective study } \\
\text { consisted of } 39 \text { women with RA. Patients were evaluated } \\
\text { in terms of seropositivity, having disease }>5 \text { years or not } \\
\text { and use of any medication. } \\
\text { Results: Rate of preterm delivery and intrauterine growth } \\
\text { retardation was } 33.3 \% \text { and } 21.2 \% \text {, respectively. } \\
\text { Comparisons between seropositive and seronegative } \\
\text { women did not show any significant difference. Having } \\
\text { disease more or less than } 5 \text { years did not show any } \\
\text { significant difference in terms of obstetric outcomes. } \\
\text { Women with a coexisting disease had a similar rate of } \\
\text { miscarriage rate compared to remainders (16.6\% vs } \\
14.8 \% \text { ). Women followed up without any medication has } \\
\text { also higher rates of miscarriage despite lack of statistical } \\
\text { significance. } \\
\text { Conclusion: Pregnancies of women with RA must be }\end{array}$ & $\begin{array}{l}\text { Amaç: Bu çalş̧manın amacı romatoid Artrit (RA) } \\
\text { hastalarının gebelik sonuçlarını değerlendirmektir. } \\
\text { Gereç ve Yöntem: Retrospektif planlanan çalışmamız } 39 \\
\text { hastadan oluşmaktadır. Hastalar seropozitivite, hastalık } \\
\text { süresinin } 5 \text { yıldan uzun olması ve ilaç kullanımı açısından } \\
\text { değerlendirildiler. } \\
\text { Bulgular: Preterm doğum ve intrauterin gelişme geriliği } \\
\text { oranı sırasıyla } 33.3 \% \text { ve } 21.2 \% \text { olarak bulundu. Seropozitif } \\
\text { ve seronegatif hastalara ilişkin yapılan karşlaştırmalarda } \\
\text { anlamlı fark izlenmedi. Hastalığın } 5 \text { yıldan uzun süredir } \\
\text { olması ya da olmamasının da gebelik sonuçlarına etki } \\
\text { etmediği görüldü. Ek bir hastalığ olanlarda ise diğer } \\
\text { hastalarda benzer oranda düşük izlendi (\%16.6, \%14.8). } \\
\text { İlaçsız olarak izlenen hastalarda ise istatistiksel farklılık } \\
\text { olmamasına rağmen daha yüksek oranda düşük izlendi. } \\
\text { Sonuç: RA tanısı olan gebeliklerin preterm doğum ya da } \\
\text { intrauterin gelişme geriliği gibi komplikasyonların daha s1k } \\
\text { izlenmesi nedeniyle yüksek riskli gebelikler olarak } \\
\text { değerlendirilmesi gerekmektedir. }\end{array}$ \\
\hline
\end{tabular}
considered as high risk due to increased rates of adverse pregnancy outcomes such as preterm delivery and intrauterine growth retardation.

Keywords: Pregnancy, rheumatoid arthritis, obstetric outcome, miscarriage.

Anahtar kelimeler: Gebelik, romatoid artri,; gebelik sonucu, düşük.

\section{INTRODUCTION}

The relationship between maternal chronic systemic inflammatory diseases and poor obstetric outcomes is a well known condition and widely studied for many autoimmune diseases ${ }^{1,2}$. Rheumatoid Arthritis (RA) with a prevalence of $0.41-0.54 \%$ is one of the most common rheumatologic diseases which predominantly affects women at childbearing age ${ }^{3}$. Thus, the management of these patients during

pregnancy is the concern of all perinatologists and rheumatologists. The relationship between obstetric outcomes and RA is still debatable. Previous literature demonstrates increased rates of adverse outcomes such as spontaneous abortion, preterm delivery or slightly reduced fetal weight in women with RA, while some other studies show no significant relationship between RA and pregnancy outcomes $^{4,5}$. Certain medications are also related to poor obstetric outcomes which are also one of the

Yazışma Adresi/Address for Correspondence: Dr. Erdem Fadıloğlu, Hacettepe University, Division of Perinatology, Department of Obstetrics and Gynecology, Ankara, Turkey E-mail: erdemfadiloglu@hacettepe.edu.tr

Geliş tarihi/Received: 24.12.2019 Kabul tarihi/Accepted: 24.03.2020 Çevrimiçi yayın/Published online: 20.05.2020 
main factors contributing to the poor obstetric outcomes in RA patients ${ }^{6}$. Beyond obstetric outcomes, some of the medications used widely in RA are contraindicated due to severe teratogenicity which also makes the management of these patients more challenging ${ }^{7}$.

Pregnancy is related to improved disease activity which is mostly related to physiologic immunosuppression during pregnancy ${ }^{8}$. Previous studies have reported improvement rates as $53-90 \%$ and remission rates in the third trimester as $27 \%$. On the other hand, the disease may flare up or activate during pregnancy at $29 \%$ of women which may severely affect life quality ${ }^{10}$.

In this study, we evaluated the obstetric outcomes of women with RA. We aimed to compare obstetric outcomes in terms of seropositivity, duration of disease and medication usage.

\section{MATERIALS AND METHODS}

This is a retrospective study evaluating obstetric outcomes of 39 women with RA between 2006 and 2019. Required data was obtained from the electronic database of our institution and Perinatology Division registries. Women with RA were followed up by the Perinatology Division and Rheumatology Division of our institution upon the diagnosis of pregnancy. Routine antenatal care programs for high risk pregnancies was applied according to national and international guidelines. Medical treatments regarding RA were administered and regulated by Rheumatology Division. The ethical approval for this study was obtained from Hacettepe University Noninterventional Clinical Research Ethical Board (12.04.2019, with a decision number of 2019/09-20). The study was conducted in accordance with the Declaration of Helsinki.

\section{Procedure}

Demographic information and patient characteristics were recorded for all patients. Patients were classified according to seropositivity or seronegativity based on previous literature according to the positivity of either RF or Anti-cyclic citrullinated peptide (ACPA). A Rheumatoid Factor level of $20 \mathrm{IU} / \mathrm{ml}$ was used as a threshold for seropositivity or negativity ${ }^{11}$. Anticyclic citrullinated peptide (ACPA) positivity was also checked for the detection of seropositivity ${ }^{12}$. Any coexisting systemic disease related to poor obstetric outcomes is also recorded as coexisting diseases. Patients were also classified according to medical treatment during pregnancy as drug free, single medication and multiple medications. Hospitalization for any obstetric indication or rheumatoid problem was recorded. Pregnancy outcomes were given as miscarriage or delivery. The gestational week of the event was recorded for both outcomes. Statistics regarding delivery outcomes were performed after the exclusion of cases resulted with miscarriage. Rate of preterm delivery and any obstetric complication was also recorded. Gestational week at delivery and birthweight were also evaluated. Birthweights less than 10th percentile according to gestational week was defined as Intrauterine Growth Retardation (IUGR) ${ }^{13}$. The duration of postpartum hospitalization was also given in days. Neonatal outcomes such as admission to Neonatal Intensive Care Unit (NICU) and APGAR score below 7 at the first 10 minutes were also recorded with the indications of NICU admission. Women without adequate clinical information or regular follow-up were excluded from the data. Women delivered at other institutions or referred to our clinic beyond the first trimester were also excluded from the study.

\section{Statistical analysis}

The data were evaluated using descriptive statistics and Mann-Whitney U test due to lack of normal distribution of cases. Chi-square test or Fisher's exact test was performed for categoric variables. Results were given as median (interquartile range) or percentiles. A $\mathrm{p}$ value $<0.05$ was considered significant. All statistical calculations were performed using Statistical Package for Social Sciences (SPSS) for Windows (SPSS version 23; SPSS Inc., Chicago, IL, USA) software package.

\section{RESULTS}

This is a retrospective study of 39 pregnancies with RA. Demographic characteristics and obstetric outcomes of all patients are summarized in Table 1. All women had a history of RA with a median duration of 6 (8) years. Seropositivity was detected in $7(17.9 \%)$ cases. Twelve out of 39 (30.7\%) women had a coexisting disease that may impair obstetric outcomes such as hypo/hyperthyroidisim, Gestational Diabetes Mellitus or Sjogren's disease. Nearly half $(46.2 \%)$ of the women were under control without any medication, while the remainders necessitated single or multiple medications (30.8\% 
and $23.1 \%$; respectively). Twelve out of thirty-nine $(30.7 \%)$ women were using Disease Modifying Anti-
Rheumatic Drugs (DMARD) alone or with a combination including corticosteroids.

Table 1. Demographic characteristics and obstetric outcomes of patients with Rheumatoid Arthritis

\begin{tabular}{|c|c|}
\hline Variable & $\mathrm{N}(\%)$ \\
\hline $\mathrm{Age}^{\ddagger}$ & $34(5)$ \\
\hline Gravida $^{\ddagger}$ & $2(2)$ \\
\hline Parity $^{\ddagger}$ & $1(2)$ \\
\hline Living Child ${ }^{\ddagger}$ & $1(2)$ \\
\hline Duration of Disease (Years $)^{\ddagger}$ & $6(8)$ \\
\hline \multicolumn{2}{|l|}{ Seropositivity $\gamma$} \\
\hline Seropositive Disease & $7(17.9 \%)$ \\
\hline Seronegative Disease & $32(82.1 \%)$ \\
\hline Coexisting Disease $\gamma$ & $12(30.7 \%)$ \\
\hline \multicolumn{2}{|l|}{ Medication During Pregnancy } \\
\hline None & $18(46.2 \%)$ \\
\hline Single & $12(30.8 \%$ \\
\hline Corticosteroids & $9(23.1 \%)$ \\
\hline Sulfasalazine & $3(7.6 \%)$ \\
\hline Multiple & $9(23.1 \%)$ \\
\hline Corticosteroids + Hydroxychloroquine & $6(15.2 \%)$ \\
\hline Corticosteroids + Sulfasalazine & $2(5.1 \%)$ \\
\hline Corticosteroids + Sulfasalazine + Hydroxychloroqine & $1(2.5 \%)$ \\
\hline Hospitalization During Pregnancy & $9(23.1 \%)$ \\
\hline \multicolumn{2}{|l|}{ Gestational Outcomer } \\
\hline Miscarriage & $6(15.4 \%)$ \\
\hline$<10$ Weeks & $3(7.7 \%)$ \\
\hline$\geq 10$ Weeks & $3(7.7 \%)$ \\
\hline Delivery & $33(84.6 \%)$ \\
\hline Vaginal Delivery & $2(5.1 \%)$ \\
\hline Cesarean Section & $31(79.4 \%)$ \\
\hline Primary Cesarean Section & $11(28.2 \%)$ \\
\hline Previous Uterine Surgery & $20(51.2 \%)$ \\
\hline \multicolumn{2}{|l|}{ Route of Delivery } \\
\hline Vaginal Delivery & $2(5.1 \%)$ \\
\hline Cesarean Section & $31(79.4 \%)$ \\
\hline Primary Cesarean Section & $11(28.2 \%)$ \\
\hline Gestational Week at Abortion ${ }^{\ddagger}$ & $10(5)$ \\
\hline Gestational Week at Delivery $^{\dagger}$ & $37(2)$ \\
\hline Preterm Delivery $\gamma$ & $11 / 33(33.3 \%)$ \\
\hline Birthweight $^{\dagger}$ & $3010(1020)$ \\
\hline \multicolumn{2}{|l|}{ Obstetric Complications $\gamma$} \\
\hline Intrauterine Growth Retardation & $7 / 33(21.2 \%)$ \\
\hline Placenta Accreata & $2 / 33(6.1 \%)$ \\
\hline Preeclampsia / Hypertensive Disease of Pregnancy & $2 / 33(6.1 \%)$ \\
\hline Acute Fatty Liver of Pregnancy & $1 / 33(3 \%)$ \\
\hline Duration of Postpartum Hospitalization ( Days ) & $2(18)$ \\
\hline \multicolumn{2}{|l|}{ APGAR scores $\gamma$} \\
\hline$<7$ & $4 / 33(12.1 \%)$ \\
\hline$\geq 7$ & $29 / 33(87.9 \%)$ \\
\hline Admissions to NICUr & $11 / 33(33.3 \%)$ \\
\hline Prematurity & $6(18.1 \%)$ \\
\hline Hypoglycemia & $2(6.6 \%)$ \\
\hline Respiratory Distress & $2(6.6 \%)$ \\
\hline Neonatal Jaundice & $1(3.3 \%)$ \\
\hline
\end{tabular}

${ }^{\ddagger}$ Median (Interquartile Range) values and $\gamma$ Rate of event are given. 
Table 2. Comparison of seropositive and seronegative patients in terms of obstetric outcomes

\begin{tabular}{|c|c|c|c|}
\hline & $\begin{array}{c}\text { Seropositive Rheumatoid } \\
\text { Arthritis } \\
(\mathrm{n}=7)\end{array}$ & $\begin{array}{c}\text { Seronegative Rheumatoid } \\
\text { Arthritis } \\
(\mathrm{n}=32)\end{array}$ & $\mathrm{p}$ \\
\hline Hospitalization during pregnancy? & $2(28.5 \%)$ & $7(21.8 \%)$ & 0.520 \\
\hline \multicolumn{4}{|l|}{ Gestational Outcomer } \\
\hline Miscarriage & $2(28.5 \%)$ & $4(12.5 \%)$ & \multirow[t]{2}{*}{0.290} \\
\hline Delivery & $5(71.5 \%)$ & $28(87.5 \%)$ & \\
\hline${\text { Gestational Week at Delivery }{ }^{\ddagger}}$ & $37(2)$ & $37(2)$ & 0.641 \\
\hline Preterm Delivery $\gamma$ & $1(20 \%)$ & $10(35.7 \%)$ & 0.643 \\
\hline Birthweight $^{\dagger}$ & $2730(430)$ & $3015(1025)$ & 0.940 \\
\hline \multicolumn{4}{|l|}{ APGAR scores $\gamma$} \\
\hline$<7$ & $1(20 \%)$ & $3(10.7 \%)$ & \multirow[b]{2}{*}{0.500} \\
\hline$\geq 7$ & $4(80 \%)$ & $25(89.3 \%)$ & \\
\hline Admissions to NICUr & $2(40 \%)$ & $9(32.1 \%)$ & 0.550 \\
\hline
\end{tabular}

${ }^{\ddagger}$ Median (Interquartile Range) values and $\gamma$ Rate of event are given. Rates related to delivery outcomes are calculated according to number of deliveries in the group.

Nine out of 39 patients hospitalized due to obstetric indications while none of them required hospitalization for RA flare up. Six pregnancies (15.4 $\%$ ) in our cohort ended up with miscarriage, while the remaining $33(84.6 \%)$ pregnancies ended up with live births. Median maternal age was 36 (4) at patients with a miscarriage, while remainders had a median age of $33(6)$ (p: 0.161). The rate of preterm delivery was $33 \%$, while IUGR was detected in $21.2 \%$ of all cases. The majority of the fetuses had an APGAR score of 7 or more at first 10 minutes, while $12.1 \%$ of the fetuses had at least one APGAR score less than 7 in the first 10 minutes. Additionally, 33\% of the fetuses admitted to NICU due to prematurity, hypoglycemia, respiratory distress and neonatal jaundice at 6,2,2 and 1 cases, respectively. None of the newborns had a major congenital anomaly.
Further comparisons were performed between seropositive and seronegative patients (Table 2). Slightly higher miscarriage rates were detected in seropositive women despite lack of statistical significance $(28.5 \%$ vs $12.5 \%$; p: 0.290$)$. Other comparisons regarding obstetric outcomes also showed no statistically significant difference between groups.

We also compared patients in terms of duration of the disease by classifying patients into two groups as having disease less than five years or more. Pregnant women having a disease more than 5 years had higher rates of preterm delivery and APGAR scores less than $<7$ despite lack of statistical significance $(40 \%$ vs $23.1 \%$ and $40 \%$ vs $23.1 \%$; $: 0.267$ and p:0.267; respectively) (Table 3 ).

Table 3. Comparison of patients according to duration of disease in terms of obstetric outcomes

\begin{tabular}{|c|c|c|c|}
\hline & $\begin{array}{l}\text { Duration of Disease } \\
\leq 5 \text { Years }(n=16)\end{array}$ & $\begin{array}{l}\text { Duration of Disease } \\
>5 \text { Years }(n=23)\end{array}$ & $\mathrm{p}$ \\
\hline Hospitalization During Pregnancy? & $4(25 \%)$ & $5(21.7 \%)$ & 0.554 \\
\hline \multicolumn{4}{|l|}{ Gestational Outcomer } \\
\hline Miscarriage & $3(18.7 \%)$ & $3(13 \%)$ & \multirow[t]{2}{*}{0.478} \\
\hline Delivery & $13(81.1 \%)$ & $20(86.9 \%)$ & \\
\hline${\text { Gestational Week at Delivery }{ }^{\ddagger}}$ & $37(1)$ & $37(4)$ & 0.782 \\
\hline Preterm Delivery $\gamma$ & $3(23.1 \%)$ & $8(40 \%)$ & 0.267 \\
\hline Birthweight $^{\ddagger}$ & $3160(620)$ & $2610(1185)$ & 0.394 \\
\hline \multicolumn{4}{|l|}{ APGAR scores $\gamma$} \\
\hline$<7$ & $3(23.1 \%)$ & $8(40 \%)$ & \multirow[t]{2}{*}{0.267} \\
\hline$\geq 7$ & $13(76.9 \%)$ & $12(60 \%)$ & \\
\hline Admissions to NICUr & $3(23.1 \%)$ & $8(40 \%)$ & 0.267 \\
\hline
\end{tabular}

${ }^{*}$ Median (Interquartile Range) values and $\gamma$ Rate of event are given. Rates related to delivery outcomes are calculated according to number of deliveries in the group 
In this study, presence of coexisting disease(s) was not found to be associated with higher rates of miscarriage (16.6\% vs $14.8 \%$; p:0.612). We also could not demonstrate statistically significant difference between these two groups in terms of APGAR scores and admissions to NICU (p:0.351 and p:0.440, respectively) (Table 4). Finally, we compared women having a medication or not during pregnancy for RA (Table 5). Women having medical treatment during pregnancy were found to have less miscarriages than the remainders without significant difference $(4.7 \%$ vs $27.7 \%$; p:0.061). Other comparisons showed no statistical significance difference between groups.

Table 4. Comparison of patients according to coexisting diseases in terms of obstetric outcomes

\begin{tabular}{|c|c|c|c|}
\hline & $\begin{array}{c}\text { Additional Disease } \\
(\mathrm{n}=12)\end{array}$ & $\begin{array}{l}\text { Lack of Coexisting } \\
\text { Disease }(n=27)\end{array}$ & $\mathrm{p}$ \\
\hline Hospitalization During Pregnancy? & $3(25 \%)$ & $6(22.2 \%)$ & 0.576 \\
\hline \multicolumn{4}{|l|}{ Gestational Outcomer } \\
\hline Miscarriage & $2(16.6 \%)$ & $4(14.8 \%)$ & \multirow[t]{2}{*}{0.612} \\
\hline Delivery & $10(83.4 \%)$ & $23(85.2 \%)$ & \\
\hline 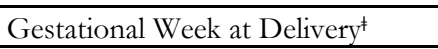 & $37(2)$ & $37(4)$ & 0.952 \\
\hline Preterm Delivery & $3(30 \%)$ & $8(34.7 \%)$ & 0.560 \\
\hline Birthweight $^{\ddagger}$ & $2720(690)$ & $3160(1210)$ & 0.307 \\
\hline \multicolumn{4}{|l|}{ APGAR scores $\gamma$} \\
\hline$<7$ & $2(20 \%)$ & $2(8.6 \%)$ & \multirow[t]{2}{*}{0.351} \\
\hline$\geq 7$ & $8(80 \%)$ & $21(81.4 \%)$ & \\
\hline Admissions to NICUr & $4(40 \%)$ & $7(28 \%)$ & 0.440 \\
\hline
\end{tabular}

${ }^{\ddagger}$ Median (Interquartile Range) values and $\gamma$ Rate of event are given. Rates related to delivery outcomes are calculated according to number of deliveries in the group.

Table 5. Comparison of patients according to medical treatment in terms of obstetric outcomes

\begin{tabular}{|c|c|c|c|}
\hline & $\begin{array}{c}\text { Follow-up without } \\
\text { Medication } \\
(\mathrm{n}=18)\end{array}$ & $\begin{array}{c}\text { Medical Treatment During } \\
\text { Pregnancy } \\
(\mathrm{n}=21)\end{array}$ & $\mathrm{p}$ \\
\hline Hospitalization During Pregnancy? & $2(11.1 \%)$ & $7(33.3 \%)$ & 0.103 \\
\hline \multicolumn{4}{|l|}{ Gestational Outcomer } \\
\hline Miscarriage & $5(27.7 \%)$ & $1(4.7 \%)$ & \multirow[t]{2}{*}{0.061} \\
\hline Delivery & $13(72.3 \%)$ & $20(95.3 \%)$ & \\
\hline${\text { Gestational Week at Delivery }{ }^{*}}$ & $38(4)$ & $37(2)$ & 0.315 \\
\hline Preterm Delivery $\gamma$ & $4(30.7 \%)$ & $7(35 \%)$ & 0.554 \\
\hline Birthweight $^{\ddagger}$ & $3290(1540)$ & $2870(860)$ & 0.888 \\
\hline \multicolumn{4}{|l|}{ APGAR scores $\gamma$} \\
\hline$<7$ & $2(15.3 \%)$ & $2(10 \%)$ & \multirow[t]{2}{*}{0.519} \\
\hline$\geq 7$ & $11(84.7 \%)$ & $18(90 \%)$ & \\
\hline Admissions to NICUr & $5(38.4 \%)$ & $6(30 \%)$ & 0.446 \\
\hline
\end{tabular}

${ }^{\ddagger}$ Median (Interquartile Range) values and $\gamma$ Rate of event are given. Rates related to delivery outcomes are calculated according to number of deliveries in the group.

\section{DISCUSSION}

Pregnancy outcomes of women with RA are controversial as discussed widely in the literature. Most possible etiological factor related to poor obstetric outcome in autoimmune disorders is reported to be the placental inflammation taking place at the maternal-fetal interface (injury of intervillous space structures; endothelial cells of spiral veins, syncytiotrophoblasts covering the chorionic villi, superficial and glandular epithelial cells in the decidua, endovascular trophoblasts) ${ }^{14-17}$. Therefore, the management of these women with immunosupressive therapies is critical for favorable obstetric outcomes. We have conducted this study for demonstrating the obstetric outcomes of these patients in a tertiary center in Turkey. There is limited data on this issue in current literature, thus we believe that our findings may be pioneering for further studies. Presentation of these data is also highly 
important, as these studies guide physicians for management of their patients. In our study, our major finding was slighly increased rates of adverse outcomes like miscarriage in women with seropositive disease, coexisting disease or RA with more than 5 years of follow-up.

In our study, nearly half of the patients were not under medical treatment during pregnancy. It has also been reported that $35 \%$ of pregnant women with RA were not under treatment which is similar to our results ${ }^{9}$. Furthermore, twelve out of 39 (30.7\%) patients were under DMARD treatment. Recent studies are showing the reliability and effectiveness of DMARD during pregnancy and the rate of DMARD usage in this study is similar to previous studies 9

In our study, $15.4 \%$ of the pregnancies ended up with a miscarriage which is much higher than the previously reported rate of $10.7 \%$ from our institution ${ }^{18}$. This rate is comparable with the previous literature reporting a rate of $17.3 \%{ }^{19}$. Maternal age at women with miscarriage was found to be higher compared to remainders, despite lack of a statistical significance most probably due to a low number of cases. Furthermore, the rate of preterm delivery $(33 \%)$ was significantly higher than the normal population which is consistent with previous studies ${ }^{20}$. IUGR, which is mostly related to placental inflammation in autoimmune diseases, was found with a rate of $21.2 \%$ which is higher than previously reported studies ${ }^{21}$. In our cohort, the NICU admission rate was determined as $33.3 \%$ which is most probably related to increased rates of IUGR and preterm delivery related to RA.

Further statistical analysis was performed for comparison between seropositive and seronegative patients. None of the parameters showed a statistically significant difference between groups most probably due to the low number of cases. However, the miscarriage rate was higher in the seropositive group compared to the seronegative group despite lack of statistical significance $(28.5 \%$ vs $12.5 \%$; p:0.290). There is limited data about the comparison of pregnancy outcomes of seropositive and seronegative patients. It has been reported that seronegative women tend to have decreased disease activity during pregnancy which may also result in milder forms of systemic inflammation which is also related to better obstetric outcomes ${ }^{22}$. ACPA positive patients are more frequently under Methotrexate treatment prior to pregnancy which is also most probably related to poor obstetric outcomes ${ }^{19}$.

Analysis regarding the duration of the disease showed no significant difference between groups. Thus, we may conclude that status of the disease may be more important than the duration of disease in terms of obstetric outcome.

The existence of coexisting disease also showed no significant difference between groups. However, it is known that increased systemic inflammatory reaction due to additional autoimmune diseases or metabolic disorders such as hypo/hyperthyroidism and Gestational Diabetes Mellitus are also related to poor obstetric outcomes.

Comparisons between treatment modalities also showed no statistical significance between groups. However, the miscarriage rate was higher at women without any medication (27.7\% vs $4.7 \%$; p:0.061). This finding may be explained by the suppression of the inflammatory reaction which may impair implantation. The effect of anti-inflammatory treatment modalities on the obstetric outcomes has also been reported previously which is consistent with our finding ${ }^{23}$. But, still these results must be interpreted carefully due to the potentially toxic effects of medications at the fetus. In our series, none of the fetuses had a major congenital anomaly. Our treatment modalities, which is consisted of glucocorticoids, hydroxychloroquine and sulfasalazine in our cohort, are reported to be favorable in the literature. Despite that, Biologic Agents are widely used in the literature and reported to be safe in pregnancy 24 .

Limitations of this study are relatively low number of cases and retrospective design. Another important limitation of this study is the distribution of seropositive and seronegative cases at this specific cohort. On the other hand, single center follow-up of patients and comparison of many factors including seropositivity or treatment modalities are the strengthts of this study.

In conclusion, pregnancies of women with RA must be considered as high risk due to increased rates of adverse outcomes such as preterm delivery and IUGR. Seropositivity, having disease more than 5 years, having a coexisting disease or using medications are not significantly related to poor outcomes compared to remainders despite slightly increased rates of miscarriage in seropositive women, women with a disease duration of 5 years and longer, 
and patients with coexisting disease. However, further prospective studies with a larger number of cases should be carried out to confirm our results.

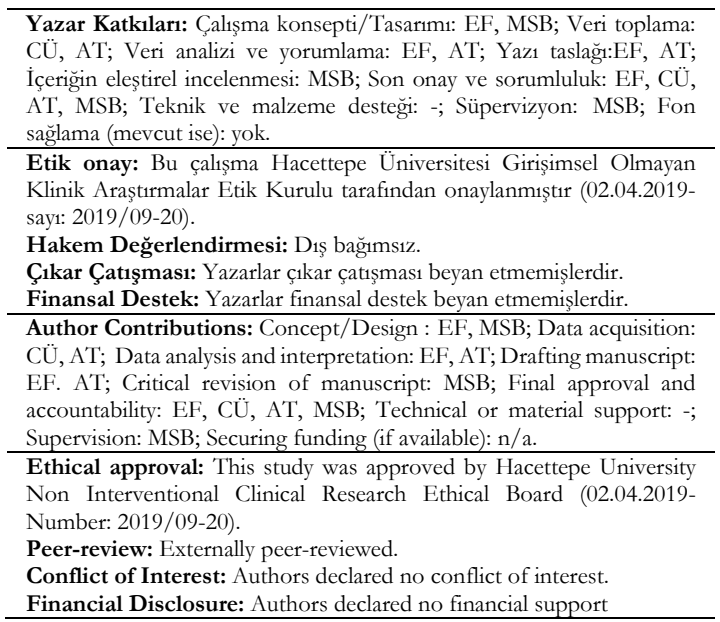

\section{REFERENCES}

1. Tanacan A, Unal C, Yucesoy HM, Duru SA, Beksac MS. Management and evaluation of pregnant women with Takayasu arteritis. Arch Gynecol Obstet. 2019;299:79-88.

2. Tanacan E, Tanacan A, Fadiloglu E, Unal C, Beksac MS. Psoriasis and pregnancy: retrospective evaluation of 47 pregnancies in a tertiary center. Gynecology Obstetrics \& Reproductive Medicine. 2019;25:128-32.

3. Hunter TM, Boytsov NN, Zhang X, Schroeder K, Michaud K, Araujo AB. Prevalence of rheumatoid arthritis in the United States adult population in healthcare claims databases, 2004-2014. Rheumatol Int. 2017;37:1551-7.

4. Rom AL, Wu CS, Olsen J, Kjaergaard H, Jawaheer D, Hetland ML et al. Fetal growth and preterm birth in children exposed to maternal or paternal rheumatoid arthritis: a nationwide cohort study. Arthritis Rheumatol. 2014;66:3265-73.

5. Ince-Askan H, Dolhain RJ. Pregnancy and rheumatoid arthritis. Best Pract Res Clin Rheumatol. 2015;29:580-96.

6. de Jong PH, Dolhain RJ. Fertility, pregnancy, and lactation in rheumatoid arthritis. Rheum Dis Clin North Am. 2017;43:227-37.

7. Temprano KK, Bandlamudi R, Moore TL. Antirheumatic drugs in pregnancy and lactation. Semin Arthritis Rheum. 2005;35:112-21.

8. de Man YA, Dolhain RJ, van de Geijn FE, Willemsen SP, Hazes JM. Disease activity of rheumatoid arthritis during pregnancy: results from a nationwide prospective study. Arthritis Rheum. 2008;59:1241-8.

9. De Man YA, Dolhain RJ, Van De Geijn FE, Willemsen SP, Hazes JM. Disease activity of rheumatoid arthritis during pregnancy: results from a nationwide prospective study. Arthritis Care Res. 2008;59:1241-8.

10. van den Brandt $\mathrm{S}$, Zbinden A, Baeten D, Villiger PM, Ostensen M, Forger F. Risk factors for flare and treatment of disease flares during pregnancy in rheumatoid arthritis and axial spondyloarthritis patients. Arthritis Res Ther. 2017;19:64.

11. Teitsson I, Withrington R, Seifert M, Valdimarsson H. Prospective study of early rheumatoid arthritis. I. Prognostic value of $\operatorname{IgA}$ rheumatoid factor. Ann Rheum Dis. 1984;43:673-8.

12. Nishimura K, Sugiyama D, Kogata Y, Tsuji G, Nakazawa T, Kawano $S$ et al. Meta-analysis: diagnostic accuracy of anti-cyclic citrullinated peptide antibody and rheumatoid factor for rheumatoid arthritis. Ann Intern Med. 2007;146:797-808.

13. Unterscheider J, Daly S, Geary MP, Kennelly MM, McAuliffe FM, O'Donoghue K et al. Optimizing the definition of intrauterine growth restriction: the multicenter prospective PORTO Study. Am J Obstet Gynecol. 2013;208:290.e1-6.

14. Mumusoglu S, Beksac MS, Ekiz A, Ozdemir P, Hascelik G. Does the presence of autoantibodies without autoimmune diseases and hereditary thrombophilia have an effect on recurrent pregnancy loss? J Matern-Fetal Neonatal Med. 2016;29:2352-7.

15. Beksaç K, Örgül G, Çağan M, Karaağaoğlu E, Arslan S, Beksaç MS. Retrospective evaluation of pregnant women with celiac disease. J Turk Ger Gynecol Assoc 2017; 18:56-9.

16. Beksac K, Orgul G, Can GS, Oktem A, Kav T, Beksac MS. Management of inflammatory bowel disease and pregnancy using prophylactic low dose low molecular weight heparin and corticosteroids. J Clin Diagn Res. 2017;11(11): QR01-3.

17. Turgal M, Gumruk F, Karaagaoglu E, Beksac MS. Methylenetetrahydrofolate reductase polymorphisms and pregnancy outcome. Geburtshilfe und Frauenheilkunde. 2018;78:871-8.

18. Örgul G, Soyak B, Aydın E, Tanaçan A, Çağan M, Beksaç MS. 22 Haftayı Geçemeyen Gebelikler. Jinekoloji-Obstetrik ve Neonatoloji Tip Dergisi. 2017;14:66-9

19. Brouwer J, Laven JS, Hazes JM, Dolhain RJ. Brief report: miscarriages in female rheumatoid arthritis patients: associations with serologic findings, disease activity, and antirheumatic drug treatment. Arthritis Rheumatol. 2015;67:1738-43.

20. Langen ES, Chakravarty EF, Liaquat M, El-Sayed YY, Druzin ML. High rate of preterm birth in pregnancies complicated by rheumatoid arthritis. Am J Perinatol. 2014;31:9-14.

21. Davutoglu EA, Ozel A, Yilmaz N, Madazli R. Pregnancy outcome in 162 women with rheumatic diseases: experience of a university hospital in Turkey. Arch Gynecol Obstet. 2017;296:1079-84. 
22. de Man YA, Bakker-Jonges LE, Goorbergh CM, Tillemans SP, Hooijkaas H, Hazes JM, et al. Women with rheumatoid arthritis negative for anti-cyclic citrullinated peptide and rheumatoid factor are more likely to improve during pregnancy, whereas in autoantibody-positive women autoantibody levels are not influenced by pregnancy. Ann Rheum Dis. 2010;69:420-3.
23. Bujold E, Roberge S, Lacasse Y, Bureau M, Audibert F, Marcoux S, et al. Prevention of preeclampsia and intrauterine growth restriction with aspirin started in early pregnancy: a meta-analysis. Obstet Gynecol. 2010;116:402-14.

24. Forger F, Villiger PM. Treatment of rheumatoid arthritis during pregnancy: present and future. Expert Rev Clin Immunol. 2016;12:937-44. 